REVIEW

\title{
CRITICAL POINTS ON EGG PRODUCTION: CAUSES, IMPORTANCE AND INCIDENCE OF EGGSHELL BREAKAGE AND DEFECTS
}

\author{
Pontos críticos na produção de ovos: causas, importância e incidência de \\ quebra e defeitos nas cascas dos ovos
}

\author{
Helenice Mazzuco ${ }^{1}$, Antonio Gilberto Bertechini²
}

\begin{abstract}
The occurrence of broken eggs directly depends on the quality of the shell. It is important to consider that the problem of broken eggs is not due to a single factor but a combination of factors. Shell defects, irregularities in shell shape, texture and surface are commonly observed during a regular egg laying cycle and the causes are varied. The incidence of downgraded eggs still represents an important source of economic loss for the egg industry due to products damage and need for further processing. It is possible to obtain significant reduction in the number of eggs lost due to the inferior quality of the shell attempting to an adequate nutrition, disease control, good management practices, and use of genetic lines with higher quality eggshell traits.
\end{abstract}

Index terms: Defective shell, egg industry, eggshell quality, laying hens, shell integrity.

\begin{abstract}
RESUMO
A ocorrência de ovos quebrados depende diretamente da qualidade da casca. É importante considerar que o problema de ovos quebrados não se deve a um único fator, mas sim a uma combinação de fatores. Defeitos de casca, irregularidades no formato da casca, textura e superfície são comumente observados durante um ciclo regular de postura e as causas são várias. A incidência de ovos descartados ainda representa uma importante fonte de prejuízo econômica à indústria, em razão da perda desses ovos e necessidade de processamento adicional. É possível obter significativa redução no número de ovos perdidos, pela qualidade inferior da casca ,focando-se em uma nutrição adequada, no controle de doenças do plantel, em boas práticas de produção e no uso de linhagens de aves que produzam ovos com melhor qualidade de casca.
\end{abstract}

Termos para indexação: Defeitos de casca, cadeia de ovos comerciais, qualidade da casca, poedeiras comerciais, integridade da casca.

\section{INTRODUCTION}

The quality of table eggs is dependent of diverse influences before and after oviposition. Hen's health and age, diet quality and safety and also, housing environment are intrinsic aspects that define the quality of laid eggs. After oviposition, the different stages relating to the egg manipulation, and collecting systems become important particularly the steps associated with collecting, grading and packing processes and transportation. Most of the practices applied during egg processing occur to correct potential hazards that may threat the sanitary conditions, like the cleaning and disinfection strategies targeting the eggshells.

As pointed out by Hincke et al. (2000), the incidence of eggshell breakage and downgraded eggs (cracks) remains elevated, despite improvements in shell quality by manipulation of nutritional, environmental and genetic factors. Such eggs are considered to be hazardous because their contents are exposed to bacterial pathogens and they may be used in products not thoroughly cooked. Wolc et al. (2012) indicated that the frequency of defects has been reduced substantially in commercial crosses of layer hens in the last decades as a result of intensive selection in pure lines, well-established crossing schemes, lighting control programs and improved nutrition. However, the incidence of downgraded eggs still represents an important source of economic loss for the egg industry due to products loss and need for further processing. In addition, shell formation over one laying year is biologically a stressful event and the age-related changes in shell thickness and shell ultra-structure are reflected in deteriorating physical parameters such as breaking strength (Solomon, 2010). A decline in eggshell quality is detected as hens approach the end of a laying period, (Mazzuco; Hester, 2005). In this way, the condition of the eggshell at the oviposition time can influence the incidence of shell breakage.

\footnotetext{
${ }^{1}$ Empresa Brasileira de Pesquisa Agropecuária/EMBRAPA - Suínos e Aves - Cx. P. 21 - 89.700-000 - Concordia - SC - Brasil - helenice.mazzuco@embrapa.br ${ }^{2}$ Universidade Federal de Lavras/UFLA - Lavras - MG - Brasil

Received in september 4, 2013 and approved in november 8, 2013
} 
This review covers the egg quality issues, particularly on the eggshell formation and mineralization, focusing on properties and conditions that influence the incidence of damage in the shells and the importance of shell integrity for consumers' safety and producer's revenue.

\section{IMPORTANCE OF THE EGGSHELL QUALITY}

In a natural environment, eggshells must be strong enough to prevent cracking in order to preserve the embryo until hatching. In the context of a farm, shell strength is necessary to prevent damage from handling and to preserve eggs during transport from farm to market (Altuntas; Sekeroglu, 2008). As pointed out by Washburn (1982), the occurrence of shell breakage can be categorized into a number of stages and the opportunities for breakage could occur before lay, at the point of lay, during collection, processing and shipping. The breeder industry also incur greater economic losses due to reduced chicken embryo livability and hatchability because the successful development of chicken embryos is dependent upon a robust eggshell for mechanical resistance, protection from infection, prevention of water loss, and as a primary source of calcium for the embryonic skeleton (Yang et al., 2010).

Eggs can be regarded as naturally packaged food. The eggshell serves to contain the egg contents, but it is also the first barrier against bacterial penetration and must be free from defects in order to optimize the safety of the contents for human consumption, (Mabe et al., 2003).

When examining the quality of packaging, one primarily considers the strength of the eggshell, (Hamilton, 1982). Eggs with a broken shell are of inferior quality and can be a food safety hazard. For producers, cracked and broken eggshells are also regarded as major source of economic loss (Kemps et al., 2006), once broken eggs cause economic damage in two ways: they cannot be sold as first-quality eggs and the occurrence of hair cracks raises the risk for bacterial contamination of the broken egg and of other eggs when leaking, creating problems with internal and external quality and food safety, (Mertens et al., 2006).

Once foodborne illness caused by Salmonella spp is known to be strongly associated with shell eggs and egg containing products (Howard et al., 2012) and shell contamination most likely depends on either intestinal or oviduct infection (Chousalkar; Roberts, 2012), biosecurity measures starting at the farm level should be implemented in order to control the risk factors for the introduction of Salmonella in the table egg chain.

\section{PHYSIOLOGICAL ASPECTS ON EGG FORMATION INFLUENCING EGGSHELLS}

The calcification of the eggshell is the result of a precipitation phenomenon occurring on the eggshell membrane, which takes place during passage of the egg through distinct regions of the oviduct. It is among the most rapid mineralization processes known, with a precise temporal and spatial control of its sequential formation (Nys et al., 2004). In the phase of shell formation (five hours after ovulation) the egg enters the uterus and acquires its ovoid shape by albumen plumping, that is, fluid enters the albumen causing it to grow to its final size at laying; during calcification the egg rotates, period that the linear deposition of calcium carbonate occur $(0,33 \mathrm{~g} / \mathrm{h}$ in hens $)$, as the mammillary and palisade layers are sequentially formed (Nys et al., 2004).

Albumen or egg white, in addition to its nutritional function, also serves to buffering the yolk against mechanical injury, acting as bactericide and establishing a template for the deposition of the shell membranes (Solomon, 1997). The ovum remains in the magnum approximately 2-3 hours and then moves along to the isthmus where the paired shell membranes are formed during 1 to 2 hours, (Solomon, 1997). The shell gland (tubular and pouch portions) is the place where the calcification of the eggs occurs. Calcification within the shell gland is associated with stimuli initiated by ovulation or by neuroendocrine factors that control and coordinate both, ovulation and calcium secretion (Johnson, 2000). During 20 hours, in the pouch region, the egg also acquires the bulk of the shell, which consists of $95 \%$ calcium carbonate $\left(\mathrm{CaCO}_{3}\right)$ and 5\% organic material (Solomon, 1997).

During the early phase of shell formation a firm bond should be established between the shell membranes and the first crystals to seed from the supersaturated solution of calcium carbonate in which the egg is bathed (Solomon, 2010).

\section{PROTEIN MATRIX OF THE EGGSHELL}

The enormous number of proteins found in the eggshell suggests a very complex mechanism of regulation of shell formation that would be expected to operate in different compartments of the oviduct and at a precise time interval (Arazi et al., 2009). Most interesting, eggshell formation is spatially and temporally controlled: there is a specific sequence to the appearance of eggshell matrix proteins in the uterine fluid, which corresponds to the initiation, growth and terminal phases of shell formation (Hincke et al., 2000). 
The first layers covering the egg white are the fibrillar shell membranes and on its outer part are discrete aggregations of organic material, called mammillary bodies (Panheleux et al., 1999). These are the sites where the organic matrix of the shell (shell matrix) is attached and where the initiation of calcium carbonate crystal takes place. As pointed out by the previous authors, the hard shell proper, the palisade, is organized upon this shell matrix most external layer, referred to as cuticle.

The protein components of biomineralized structures (matrix proteins) influence the properties of the final structure of calcium phosphate (hydroxyl-apatite) or calcium carbonate (calcite) by modulating nucleation and growth (Hincke et al., 2000) and also, as they are involved in the control of shell mineralization, there is a great contribution in the organization and mechanical properties of the shell due to those proteins (Nys et al., 1999).

The uterine fluid contains high levels of ionized calcium and bicarbonate such that calcite (calcium carbonate) is present 50-60 times its solubility product (Nys et al., 1999). This supersaturated solution also contains a rich variety of proteins that are mainly the precursors of the matrix proteins that become incorporated into the eggshell and which fluid composition vary according to the stage of shell formation (Hincke et al., 2000). As indicated by Panheleux et al. (1999), some of these proteins present as matrix components are: ovocleidin 17 (localized in the palisade and mammillary layer), ovoalbumin $(45 \mathrm{kDa})$, mainly present during the initial phase of the shell formation, lysozyme present in the uterine fluid; ovotransferrin, osteopontin, chondroitin-6 sulphate and dermatan sulphate proteoglycan (both present in the mammillary bodies).

\section{EGGSHELL DEFECTS: MAJOR CAUSES AND INCIDENCE}

Hincke et al. (2000) reported that, in spite of great deal of basic research into calcium metabolism and eggshell formation, the problem of weak or poor quality eggshell remains a significant factor for the industry. This is because unfortunately, there are multiple factors affecting eggshell quality like genetics of the hen, nutrition and management of feed intake, disease and environment challenge and also equipment insult.

The irregularities in shell shape, texture and surface are commonly observed during a regular egg laying cycle. The causes are varied: from factors that cause disturbance to the birds (any kind of stress) to an inadequate nutrition and lighting regimens (photoperiod) and/or diseases. As indicated by Solomon (1997), if stress is experienced before the egg reaches the shell gland, the entire process of shell formation is affected and thin-or-soft shelled eggs are commonly observed. If the shell breaks in the shell gland during the process of mineralization, shell defects as corrugated eggs and body-checked eggs will occur. A body-checked egg can be defined as one that has broken in the pouch region during the process of mineralization but that is partially repaired by additional calcification.

Wolc et al. (2012) studied eggshells defects in purebred brown-egg laying hens showing the frequency that those damages occurs (Table 1) and how substantial genetic variation was found in that studied population.

Table 1 - Summary statistics for eggshells defects in the studied population*.

\begin{tabular}{ccccc}
\hline Trait & Minimum & Mean & Maximum & SD \\
\hline \% broken egg & 0 & 0.68 & 57.14 & 2.16 \\
\% Calcium deposits & 0 & 1.23 & 43.59 & 3.13 \\
\% misshapen egg & 0 & 0.33 & 25.00 & 1.09 \\
\% shell-less & 0 & 0.24 & 92.86 & 1.54 \\
\% soft-shell & 0 & 0.28 & 44.12 & 1.28 \\
\hline
\end{tabular}

*Adapted from Wolc et al. (2012).

Besides genetic factors, any condition that causes disturbance to the birds 10-14 hours before the egg is laid, is likely to increase the incidence of these types of shell defect (Coutts; Wilson, 2007). From a poultry welfare perspective, eggshell abnormalities associated with stress-induced oviposition delays can provide a convenient (non-invasive) means of assessing stress in flocks of hens as pointed out by Hughes, Gilbert and Brown (1986). Anomalous eggshells and degree of abnormality can be used as indicators of environmental stress suffered by the flock of hens (Reynard; Savory, 1999). The previous authors showed that the duration of environmental stress and associated oviposition delay affect the number of abnormal eggshells and degree of abnormality, and hence downgrading of table eggs and possible impairment of embryonic development in the case of fertile eggs (hatching operations). Stress and diseases have the potential to influence the deposition of eggshell pigmentation during egg formation (Mertens et al., 2010). Infectious bronchitis, is an example and has been implicated in the production of "watery white", a condition observed when chemical changes in the nature of secretions from the magnum affects the shell structure of eggs (Solomon, 1997), causing the shell membranes to become arranged in a distorted manner due to the absence 
of an adequate template for the regular shell mineralization as occur in body-checked or corrugated shells. The incidence of this type of egg shell defects could reach $1 \%$ and in older birds flocks, $9 \%$ (Coutts; Wilson, 2007).

When analyzing the egg breakage in the different chains, Mertens et al., (2006) indicated the critical points associated with the egg production, starting at the farm. The conventional and furnished cage systems showed a relatively high percentage of breakage after lay, $6.73 \%$ and $10.72 \%$ respectively. The aviary and free-range system had a similar total breakage (1.94\% and $1.99 \%$, respectively) after collecting the eggs. Grading and packing seems to be the second critical point in the logistic chain after laying and collecting (Table 2). The higher breakage percentages in the collecting and packing operation indicate a possible higher risk at those points in the logistic chain. In the first case, the collecting belts in chain 1 generated an extremely high percentage $(36.85 \%)$ of broken eggs due to technical problems. Breakage due to transportation ranged from 0.16 to $2.65 \%$.

In extreme cases of egg retention, the shell gland pouch can find itself accommodating two full-sized eggs and as the second egg comes into contact with the first and at this point, the pattern of mineralization is disrupted directing the first egg to acquire a characteristic white band and the second to be flattened on its contiguous surface (Solomon, 1997). An estimate for the incidence of this type of eggshell defect is less than $1 \%$ and varies as breed of hens (Coutts; Wilson, 2007).

Another common surface defect observed in the eggshell is the coated shell, when additional calcium deposits or extracuticular coverings are observed and possibly reflects the timing and magnitude of the stress or disturbance experienced by the flock (Solomon, 1997). It's commonly observed an incidence of this defect of $1 \%$ and could be caused by the age of the birds (often younger flocks) coming into production (Coutts; Wilson, 2007).

Previously, a high incidence of breakage, about $3.5 \%$ of the eggs laid, was reported at the point of lay by Hamilton et al., (1979). As indicated by the authors, a number of variables contributes to shell damage at the point of lay like the age of the hens, the design of the cage system, number of hens, number of hens housed per cage, among others. The same authors indicated that transportation accounts for about $1 \%$ breakage of all eggs produced and this damage is influenced by factors as: amount and quality of the labour loading the vehicle, means by which the cases or cart of eggs are placed in the vehicle and secured, manner in which the vehicle is driven, nature of roads over which the vehicles travels among others.

\section{CHEMICAL COMPOSITION OF THE EGGSHELL}

The chicken eggshell comprises calcified shell and shell membranes including inner and outer membranes (Nakano; Ikawa; Ozimek, 2003).

Trace elements may also directly affect eggshell structure through a modifying effect on calcite crystal growth mechanisms and may influence eggshell quality either by their catalytic properties as key enzymes involved in the process of membrane and eggshell membrane and eggshell formation or by interacting directly with the calcite crystals in the forming eggshell, (Mabe et al., 2003).

The organic matter of eggshell contains proteins as major constituents with small amounts of carbohydrates and lipids. As pointed out by Mann et al. (2008), at the time of mineralization, the oviductal fluid apparently contains a complex mixture of proteins which not only consists of the proteins produced by cells lining the eggshell gland,

Table 2 - Percentages of broken eggs obtained from different operations in the production chains*.

\begin{tabular}{ccccc}
\hline Operation & $\begin{array}{c}\text { Chain 1 } \\
\text { Battery cages }\end{array}$ & $\begin{array}{c}\text { Chain 2 } \\
\text { Furnished cages }\end{array}$ & Chain3 Aviary & Chain 4 Free-range \\
\hline Laying & 6.73 & 10.72 & - & - \\
Collecting & 36.85 & 3.83 & 1.94 & 1.99 \\
Transport to packing station & 2.65 & 1.25 & 1.31 & 0.28 \\
Grading and packing & 3.44 & 1.50 & 2.17 & 2.11 \\
Transport do depot warehouse & - & - & - & 0.86 \\
Transport to retail store & 0.25 & 0.16 & 0.21 & 0.22 \\
Total & 44.63 & 16.61 & 5.47 & 5.36 \\
\hline
\end{tabular}

* Adapted from Mertens et al. (2006). 
but also contains proteins derived from decaying cells, partially degraded basement membranes, proteins of the secretory machinery and left-overs from egg white and eggshell membrane assembly and then, this whole mixture is incorporated into the growing mineralized shell irrespective of a possible function.

Also, the organic matter of eggshells contains two glycosaminoglycans including hyaluronic acid and chondroitin sulfate-dermatan sulfate copolymer (Nakano et al., 1994). Sialic acid is another carbohydrate found in eggshell membranes (Nakano; Ikawa; Ozimek, 2003). Also, the eggshell membranes contain relatively small but significant amounts of uronic acid.

A total of 528 proteins have now been identified in the decalcified eggshell organic matrix, including all of the previously characterized eggshell-specific proteins (ovocleidins and ovocalyxins) and proteins known to be induced by the passage of the egg from isthmus to eggshell gland, such as osteopontin and glypican-4 (Mann et al., 2008).

The structural constituent of the eggshell also has a genetic component. Average expression profiles of juvenile and sexually mature shell glands were compared using chicken cDNA microarray and resulted in the identification of 266 differentially regulated genes (Dunn et al., 2009). The differentially expressed genes included several that showed involvement in shell gland function, like transport and shell matrix proteins and some unpredicted differentially expressed genes identified in the shell gland. These genes are involved in shell formation, the production of antimicrobial peptides and the maintenance of a fully developed shell gland under the influence of ovarian steroids. These include those encoding osteoprotegerin, prostatic acid phosphatase (ACPP) and prostate stem cell antigen (PSCA), urea transporter, bactericidal permeability-increasing protein-like2 (BPIL2) and other potential anti-microbials.

Two proteins, calbindin and osteopontin (OPN) are known to be involved in calcium metabolism of the eggshell gland. Samples taken from the sharp pole corresponding part of the eggshell gland that generates eggs with cracks at the sharp pole exhibited almost no OPN gene expression, whereas calbindin expression was similar to that of the eggshell gland of layers with normal eggshells (Arazi et al., 2009). In other words, although the levels of calbindin gene expression were similar at both locations irrespective of the location of the cracks, OPN expression was almost completely absent at the location corresponding to the cracks, in contrast to its level at the opposite direction.
The importance of a single microelement for adequate eggshell formation and composition was pointed out by diverse authors: Leach and Gross (1983) observed that hens fed manganese (Mn)-deficient diets produced eggs with thinner shells, translucent areas and abnormalities in eggshell structure. In agreement, Yang et al. (2012) pointed out that an increase in eggshell thickness was observed as an effect of $\mathrm{Mn}$ supplementation $(15,35$ or $55 \mathrm{mg} / \mathrm{kg})$, more than $\mathrm{Zn}(15 \mathrm{mg} / \mathrm{kg}$ supplement) in a layer diet offered to 40 weeks-old hens. Copper $(\mathrm{Cu})$ deficiency in hens results in atypical eggshell formation characterized by abnormal distribution of the shell membrane fibers due to alterations in lysine-derived-crosslinks, which results in egg shape deformation and altered mechanical properties (Baumgartner et al., 1978). Another trace element, Zinc (Zn) is a component of the carbonic anhydrase enzyme, which is crucial for supplying the carbonate ions during eggshell formation and inhibition of this enzyme results in lowered bicarbonate ion secretion and consequently greatly reduces eggshell weight (Nys et al., 1999).

Improved breaking strength and fracture toughness (resistance to fracture) were observed by Mabe et al. (2003) in hens (60 and 69 weeks-old) after supplementing the diet of laying hens with a combination of $\mathrm{Zn}, \mathrm{Mn}$, and $\mathrm{Cu}$ from organic or inorganic sources at 1, 5, and 9 weeks after introduction of the experimental diets. The effect was observed regardless of the source of trace elements. A study conducted by the previous authors suggests that addition of organic or inorganic sources of combined $\mathrm{Zn}, \mathrm{Mn}$ and $\mathrm{Cu}$ does not significantly influence the amount of eggshell material deposited during eggshell formation but can enhance some mechanical properties like, improved breaking strength and fracture toughness (resistance to fracture) and regardless the source of trace elements. Additionally, the size and orientation of calcium carbonate crystals influence the structure and strength of the eggshells of chickens (Dunn et al., 2011). Additionally, Sun et al. (2012) investigating the variation pattern of eggshell thickness uniformity on breaking strength showed that eggs with better eggshell thickness uniformity (after measured 42 points along both longitudinal and latidudinal axis) have stronger eggshell quality.

Dunn et al. (2011) also observed a strong positive correlation (0.65) for crystal size and orientation with the thickness of the shell and, in particular, with the thickness of the mammillary layer. A fine-tuning on mineral balance should be carefully taken into account once an excess or a deficiency in the diet will compromise bird's performance. As indicated by Trindade Neto et al. (2011), eggshell 
mineral accretion was compromised when increased chelated $\mathrm{Zn}$ levels were added in the diet and the results were decreased shell weight, percentage of ash, yolk ash deposition, and total ash deposition.

As indicated by Clunies, Parks and Leeson (1992), the skeleton is the only major alternate source of calcium available to the hen during shell formation though, previously, Buss and Guyer (1984) showed that the skeletal metabolism was not a limiting factor in determining whether a hen produces a "thick" or "thin" eggshell. The previous authors conducted a study to make comparative measurements of bone parameters in lines of hens genetically divergent producing thick and thin eggshells. Results showed that the skeleton's contribution of calcium for the eggshell is the same for both lines and bone metabolism was not a cause of thick or thin eggshell production.

An interesting study was carried out by Clunies, Parks and Leeson (1992) to investigate Calcium and Phosphorus metabolism of hens laying thick or thinshelled eggs on shell forming days and days on which shell formation does not occur. Results indicated that the amount (in grams) of shell $\mathrm{Ca}$ (but not Phosphorus) were significantly greater $(\mathrm{P}<0.05)$ from hens producing thick eggshell compared with those selected to produce thin shelled eggs. Differences in shell weight and shell $\mathrm{Ca}$ content were due primarily to differences observed in the efficiency of $\mathrm{Ca}$ retention: feed intake increased significantly on birds laying during shell forming days and the same group of hens retained significantly $(\mathrm{P}<0.05)$ more calcium.

\section{CONCLUSIONS}

It is very important to understand the factors that affect the incidence of breakage of the eggs once the lower quality of the shell can lead to economic loss to the producer. The scale of shell damage varies from farm to farm and several strategies should be practice to alleviate the problem. Some are: reduction in the chance of impact, for example, collecting the eggs more often especially in older flocks; avoid the stress of hens at the farm; improve disease control (replacement system all-in, all-out and efficient vaccination programs). The genetic lines to be housed should be those that have a higher quality of shell, and carefully consider nutritional strategies to obtain more resistant shells.

\section{REFERENCES}

ALTUNTAS, E.; SEKEROGLU, A. Effect of egg shape index on mechanical properties of chicken eggs. Journal of Food Engineering, 85(4):606-612, 2008.

ARAZI, H. et al. Osteopontin and calbindin gene expression in the eggshell gland as related to eggshell abnormalities. Poultry Science, 88(3):647-653, 2009.

BAUMGARTNER, S. et al. Copper deficiency in the laying hen. Journal of Nutrition, 108(5):804-811, 1978.

BUSS, E.G.; GUYER, R.B. Bone parameters of thick and thin eggshell lines of chickens. Comparative Biochemistry and Physiology Part A: Physiology, 78(3):449-452, 1984.

CLUNIES, M.; PARKS, D.; LEESON, S. Calcium and phosphorus metabolism and eggshell thickness in laying hens producing thick or thin shells. Poultry Science, 71(3):490-498, 1992.

COUTTS, J.A.; GRAHAM, C.W. Optimum Egg Quality-A practical approach. 5M Publishing, Sheffield, GB, 2007, 65p.

CHOUSALKAR, K.K.; ROBERTS, J.R. Recovery of Salmonella from eggshell wash, eggshell crush, and egg internal contents of unwashed commercial shell eggs in Australia. Poultry Science, 91(7):1739-1741, 2012.

DUNN, I.C. et al. New hypothesis on the function of the avian shell gland derived from micro array analysis comparing tissue from juvenile and sexually mature hens. General and Comparative Endocrinology, 63(12):225-232, 2009.

DUNN, I.C. et al. Genetic variation in eggshell crystal size and orientation is large and these traits are correlated with shell thickness and are associated with eggshell matrix protein markers Animal Genetics, 43(4):410-418, 2011.

HAMILTON, R.M.J. et al. Relationship between egg shell quality and shell breakage and factors that affect shell breakage in the field - A review. World's Poultry Science Journal, 35(3):177-190, 1979.

HAMILTON, R. M. G. Methods and factors that affect the measurement of egg shell quality. Poultry Science, 61(10):2022-2039, 1982. 
HINCKE, M.T. et al. Eggshell proteins and shell strength: molecular biology of eggshell matrix proteins and industry applications. In: SIM; NAKAI; GUENTER (Eds). Egg Nutrition and Biotechnology. CABI Publishing, Wallingford, UK, 2000, 495p.

HOWARD, Z.R. et al. Salmonella enteritidis in shell eggs: Current issues and prospects for control. Food Research International, 45(2):755764, 2012.

HUGHES, B.O.; GILBERT, A.B.; BROWN, M.F. Categorisation and causes of abnormal egg shells: relationship with stress. British Poultry Science, 27(2):325-337, 1986.

JOHNSON, A. L. Reproduction in the female. In: WHITTOW, G.C. (Eds). Sturkie's Avian Physiology (Academic Press, San Diego, CA), 2000.685p.

KEMPS, B.J. et al. The influence of line and laying period on the relationship between different eggshell and membrane strength parameters. Poultry Science, 85 (7):1309-1317, 2006.

LEACH JUNIOR, R.M.; GROSS J.R. The effect of manganese deficiency upon the ultrastructure of the eggshell. Poultry Science, 62(3):499-504, 1983.

MABE, I. et al. Supplementation of a corn-soybean meal diet with manganese, copper, and zinc from organic or inorganic sources improves eggshell quality in aged laying hens. Poultry Science, 82(12):19831913, 2003.

MANN, K. et al. Identification of new chicken egg proteins by mass spectrometry-based proteomic analysis. World's Poultry Science Journal, 64(2):209218, 2008.

MAZZUCO, H.; HESTER, P.Y. The Effect of an induced molt and a second cycle of lay on skeletal integrity of white leghorns. Poultry Science, 84(5):771$781,2005$.

MERTENS, K. et al. Monitoring of eggshell breakage and eggshell strength in different production chains of consumption eggs. Poultry Science, 85(9):1670-1677, 2006.
MERTENS, K. et al. The transmission color value: A novel egg quality measure for recording shell color used for monitoring the stress and health status of a brown layer flock. Poultry Science, 89(3):609-617, 2010.

NAKANO, K. et al. Sialic acid contents in chicken eggs and tissues. Canadian Journal of Animal Science, 74(4):601-606, 1994.

NAKANO, T.; IKAWA, N.I.; OZIMEK, L. Chemical composition of chicken eggshell and shell membranes. Poultry Science, 82(3):510-514, 2003.

NYS, Y. et al. Avian eggshell mineralization. Poultry and Avian Biology Reviews, 10(3):143-166, 1999.

NYS, Y. et al. Avian eggshell mineralization: biochemical and functional characterization of matrix proteins. Comptes Rendus Palevol, 3(6-7):549-562, 2004.

PANHELEUX, M. et al. Organic matrix composition and ultrastructure of eggshell: a comparative study.

British Poultry Science, 40(2):240-252, 1999.

REYNARD, M; SAVORY, C.J. Stress-induced oviposition delays in laying hens: duration and consequences for eggshell quality. British Poultry Science, 40(5):585-591, 1999.

SOLOMON, S.E. The ovary and the oviduct. In: MANSON (Eds) Egg and eggshell quality, Manson Publishing, Ames, IA, 1997. 149p.

SOLOMON, S.E. The eggshell: strength, structure and function. British Poultry Science, 51(1):52-59, 2010.

SUN, C.J. et al. Global variation and uniformity of eggshell thickness for chicken eggs. Poultry Science, 91(7):2718-2721, 2012.

TRINDADE NETO, M. A. et al. Dietary effects of chelated zinc supplementation and lysine levels in ISA Brown laying hens on early and late performance, and egg quality. Poultry Science, 90(12):2837-2844, 2011.

WASHBURN, K.W. Incidence, cause, and prevention of egg shell breakage in commercial production. Poultry Science, 61(10):2005-2012, 1982. 
WOLC, A. et al. Genetic parameters of egg defects and egg quality in layer chickens. Poultry Science, 91(6):1292-1298, 2012.

YANG DE-J. et al. Mapping of quantitative trait loci affecting eggshell quality in an F2 population derived from strong and weak eggshell lines of the white leghorn chicken. Agricultural Sciences in China, 9(4):593-597, 2010.

YANG, X. et al. Effects of diets supplemented with zinc and manganese on performance and related parameters in laying hens. Animal Science Journal, 83(6):474481, 2012. 